\title{
Oxidative stress-induced apoptosis in granulosa cells involves JNK, p53 and Puma
}

\author{
Hongyan Yang1, Yan Xie ${ }^{1}$, Dongyu Yang ${ }^{1}$, Decheng Ren ${ }^{2}$ \\ ${ }^{1}$ Key Research Laboratory of Gynecology, Department of Gynecology, The Second Affiliated Hospital of Guangzhou University \\ of Traditional Chinese Medicine, Yuexiu District, Guangzhou, Guangdong 510120, China \\ ${ }^{2}$ Department of Medicine, The University of Chicago, Chicago, IL 60637, USA \\ Correspondence to: Decheng Ren, email: decheng@uchicago.edu \\ Hongyan Yang, email: dryanghongyan@163.com
}

Keywords: granulosa cell apoptosis, JNK, p53, Puma, $\mathrm{H}_{2} \mathrm{O}_{2}$

Received: November 14, $2016 \quad$ Accepted: February 07, $2017 \quad$ Published: February 28, 2017

Copyright: Yang et al. This is an open-access article distributed under the terms of the Creative Commons Attribution License (CC-BY), which permits unrestricted use, distribution, and reproduction in any medium, provided the original author and source are credited

\section{ABSTRACT}

Reactive oxygen species (ROS) play important roles in follicular development and survival. Granulosa cell death is associated with increased ROS, but the mechanism of granulosa cell death induced by ROS is not clear. In order to define the molecular link between ROS and granulosa cell death, COV434, human granulosa tumor cells, were treated with $\mathrm{H}_{2} \mathrm{O}_{2}$. Compared to control cells, $\mathrm{H}_{2} \mathrm{O}_{2}$ induced granulosa cell death in a dose- and time-dependent manner. $\mathrm{H}_{2} \mathrm{O}_{2}$ induced an increase in Bax, Bak and Puma, and a decrease in anti-apoptotic molecules such as $\mathrm{Bcl}-2, \mathrm{Bcl}-\mathrm{xL}$ and $\mathrm{Mcl}-1$. Both knockdown of Puma and overexpression of $\mathrm{Bcl}-\mathrm{xL}$ could inhibit $\mathrm{H}_{2} \mathrm{O}_{2}$-induced granulosa cell death. These results suggest that suppression of Puma and overexpression of antiapoptotic Bcl-2 family members could improve granulosa cell survival. To explore the mechanisms responsible for these findings, ROS in granulosa cells treatment with $\mathrm{H}_{2} \mathrm{O}_{2}$ were measured. The results showed that ROS was increased in a $\mathrm{H}_{2} \mathrm{O}_{2}$ dose- and timedependent manner at the earlier time point. In addition, $\mathrm{H}_{2} \mathrm{O}_{2}$ induced an increase in Nrf2 and phosphorylation of JNK and p53. SP600125, an inhibitor of JNK, inhibits $\mathrm{H}_{2} \mathrm{O}_{2}$-induced phosphorylation of JNK and p53, and granulosa cell death. Antioxidant $\mathrm{N}$-acetylcysteine (NAC) dose-dependently prevents $\mathrm{H}_{2} \mathrm{O}_{2}$-induced granulosa cell death. Furthermore, NAC also prevents phosphorylation of JNK and p53 induced by $\mathrm{H}_{2} \mathrm{O}_{2}$. Taken together, these data suggest that $\mathrm{H}_{2} \mathrm{O}_{2}$ regulates cell death in granulosa cells via the ROS-JNK-p53 pathway. These findings provide an improved understanding of the mechanisms underlying granulosa cell apoptosis, which could potentially be useful for future clinical applications.

\section{INTRODUCTION}

Inside the follicular microenvironment, the oocyte is surrounded by several layers of granulosa cells that are differentiated into mural and cumulus granulosa cells during final stages of folliculogenesis. The morphology and number of encircling granulosa cells have been used as biomarkers for developmental competency, embryo and pregnancy outcome [1]. Granulosa cells not only provide nutrients and maturation-enabling factors to ensure successful maturation and developmental competency of oocytes but also protect oocytes from oxidative stress damage through their own antioxidant system during maturation of oocytes [2, 3]. Female reproduction aging is caused by ovarian aging with the core theory: the increase of follicles atresia rate reduces the number of ovarian follicles with age gradually. Granulosa cell apoptosis, a physiological phenomenon in follicle, can trigger follicular atresia and are responsible for follicle numbers decrease [4]. Thus the apoptosis of ovarian granulosa cells is also the main etiological factor of premature ovarian insufficiency. Regulation of granulosa cell apoptosis can be realized through the following two signaling pathways: "mitochondrial" or the intrinsic pathway and "death receptor" or the extrinsic pathway. Death receptor pathway is triggered by the combination of death receptor 
and the ligand, such as tumor related apoptosis inducing ligand (TRAIL) and its receptor, factor associated suicide (Fas) and its ligand (FasL). Mitochondrial pathway is mainly mediated by the $\mathrm{Bcl}-2$ related proteins. The Bcl-2 family members such as Bid, Bim, Puma, Bax and Bak play a critical role in the intrinsic signaling pathway [5]. The relative contribution of extrinsic and intrinsic signaling pathways to granulosa cell apoptosis is unclear. Thus, clarifying the mechanisms responsible for ovarian granulosa cell apoptosis is important not only for understanding the pathogenesis of follicular atresia but also for developing novel approaches to prevent premature ovarian insufficiency.

Granulosa cells are sensitive to reactive oxygen species (ROS). ROS including $\mathrm{H}_{2} \mathrm{O}_{2}$ play a key role in granulosa cells apoptosis [6]. ROS, side-products formed during citric acid cycle, may cause oxidative damage through interacting with cellular lipids, proteins, and nucleic acids in cells. Increased ROS can induce oxidative stress when the balance between oxidation and reduction-regulated cellular processes is disrupted and cells cannot repair the resulting oxidative damage [7]. In human, oxidative stress may cause granulosa cell dysfunction [8]. Although endogenous $\mathrm{H}_{2} \mathrm{O}_{2}$ is an important signaling molecule, high levels of $\mathrm{H}_{2} \mathrm{O}_{2}$ may cause cell dysfunction and cell death. Exogenous $\mathrm{H}_{2} \mathrm{O}_{2}$ at concentrations $\geq 0.5 \mathrm{mM}$ can rapidly induce cytotoxicity in human granulosa cell tumor line COV434 cells, which possess many characteristics of normal granulosa cells [9]. Increasing cellular antioxidant glutathione (GSH) can protect COV434 cells against $\mathrm{H}_{2} \mathrm{O}_{2}$-induced cytotoxicity. In contrast, depletion of the GSH sensitizes granulosa cells to toxicantinduced apoptosis [9]. In addition, generation of ROS caused by ionizing radiation and chemical toxicants has also been implicated in the toxicity of granulosa cells [10]. But the mechanism of cell toxicity induced by ROS is less known.

In the present study, COV434 cells were used to determine the mechanism of granulosa cell apoptosis induced by $\mathrm{H}_{2} \mathrm{O}_{2}$. The signaling pathways that mediate the effect of $\mathrm{H}_{2} \mathrm{O}_{2}$ in COV434 cells were also identified.

\section{RESULTS}

\section{$\mathrm{H}_{2} \mathrm{O}_{2}$ induced granulosa cell death in a dose-and time-dependent manner}

$\mathrm{H}_{2} \mathrm{O}_{2}$ induced an increase in cleaved caspase 3 protein levels in a time-dependent manner (Figure 1A). Treatment of COV434 cells with $1.0 \mathrm{mM} \mathrm{H} \mathrm{O}_{2}$ for $4 \mathrm{~h}$ induced a 6-fold increase in cleaved caspase 3 (Figure 1A). $\mathrm{H}_{2} \mathrm{O}_{2}$ also timedependently induced an increase in PARP cleavage (Figure 1A). In addition, $\mathrm{H}_{2} \mathrm{O}_{2}$ dose-dependently induced an increase in cleaved caspase 3 and PARP (Figure 1B). After treatment of COV434 cells for $4 \mathrm{~h}, 1.5 \mathrm{mM} \mathrm{H}_{2} \mathrm{O}_{2}$ significantly induced an increase in cleaved PARP by 9-fold (Figure 1B). These results indicate that $\mathrm{H}_{2} \mathrm{O}_{2}$ induces ovarian granulosa cell death. Apoptotic ratios were analyzed by PI staining. Indeed, $\mathrm{H}_{2} \mathrm{O}_{2}$ at the concentration of $1.5 \mathrm{mM}$ significantly induced cell death from $7.5 \%$ at $0 \mathrm{~h}$ to $58.2 \%$ at $6 \mathrm{~h}$ (Figure 1C). The highest apoptotic ratio was observed in COV434 cells at $12 \mathrm{~h}$ after $\mathrm{H}_{2} \mathrm{O}_{2}$ treatment (Figure 1C). Immunoblot analysis also showed that Z-VAD, caspase inhibitor, significantly inhibited the increase in cleaved caspase 3 induced by $\mathrm{H}_{2} \mathrm{O}_{2}$ (Figure 1D). To further confirm that $\mathrm{H}_{2} \mathrm{O}_{2}$ treatment can cause cell apoptosis, another cell death assay, TUNEL staining, was used to measure cell apoptosis. The results showed that $\mathrm{H}_{2} \mathrm{O}_{2}$ significantly induced an increase in TUNEL positive staining from $2.1 \%$ in control cells to $38.7 \%$ in $\mathrm{H}_{2} \mathrm{O}_{2}$ treatment cells (Figure $1 \mathrm{E}$ and $1 \mathrm{~F}$ ), indicating more cells died after $\mathrm{H}_{2} \mathrm{O}_{2}$ treatment. These results suggest that $\mathrm{H}_{2} \mathrm{O}_{2}$ significantly induces COV434 cell death in both dose- and time-dependent manner.

\section{Bcl-2 family members are involved in $\mathrm{H}_{2} \mathrm{O}_{2}-$ induced granulosa cell death}

The Bcl-2 family has both pro-apoptotic members including Bid, Bim, Puma, Bax and Bak and antiapoptotic members such as Bcl-2, Bcl-xL and Mcl-1. To determine whether $\mathrm{H}_{2} \mathrm{O}_{2}$ can change the expression levels of these molecules, we measured the protein levels of Bcl2 family members. The results showed that $\mathrm{H}_{2} \mathrm{O}_{2}$ dosedependently induced an increase in protein levels of Bax and Bak. $\mathrm{H}_{2} \mathrm{O}_{2}$ at $1.0 \mathrm{mM}$ significantly increased Bax and Bak in COV434 cells at $6 \mathrm{~h}$ by $40 \%$ and $90 \%$, respectively (Figure 2A). Furthermore, $\mathrm{H}_{2} \mathrm{O}_{2}$ also induced an increase in Bax and Bak in a dose-dependent manner. $0.5 \mathrm{mM} \mathrm{H}_{2} \mathrm{O}_{2}$ induced an increase in Bax protein levels by $40 \%$ at $4 \mathrm{~h}$ and Bak protein levels by $90 \%$ at $6 \mathrm{~h}$ (Figure $2 \mathrm{~B}$ ). Other Bcl-2 family members were also determined. $\mathrm{H}_{2} \mathrm{O}_{2}$ dosedependently induced a decrease in Bcl-2, Bcl-xL and Mcl1 and an increase in Puma at $4 \mathrm{~h}$ (Figure 2C). $1.5 \mathrm{mM} \mathrm{H}_{2} \mathrm{O}_{2}$ induced a decrease in $\mathrm{Bcl}-\mathrm{xL}$ and $\mathrm{Mcl}-1$ protein levels at $4 \mathrm{~h}$ by $50 \%$ and $90 \%$, respectively, and an increase $1.3-$ fold Puma levels. But the levels of A1, Bid and Bad were not changed by $\mathrm{H}_{2} \mathrm{O}_{2}$ treatment ingranulosa cells (Figure 2C). Surprisingly, Bim was decreased rather than increased after $\mathrm{H}_{2} \mathrm{O}_{2}$ treatment. Morevoer, $\mathrm{H}_{2} \mathrm{O}_{2}$ at $1.0 \mathrm{mM}$ significantly induced a decrease in protein levels of Bcl2, Bcl-xL, Bim and Mcl-1 and an increase in Puma in a time-dependent fashion (Figure 2D). However, the protein levels of A1 were unchanged and tBid was undetectable (Figure 2D). Interestingly, Mcl-1 was decreased after $1.0 \mathrm{mM} \mathrm{H} \mathrm{O}_{2}$ treatment at 2 and $4 \mathrm{~h}$, but increased at $6 \mathrm{~h}$ although it was not fully recovered. Taken together, these results suggest that $\mathrm{H}_{2} \mathrm{O}_{2}$ both dose-and time-dependently induces Bax, Bak and Puma up-regulation and Bcl-2, Bcl$\mathrm{xL}$ and Mcl-1 down-regulation in COV434 cells.

\section{Puma contributes to $\mathrm{H}_{2} \mathrm{O}_{2}$-induced granulosa cell death}

To determine whether Puma up-regulation plays a role in granulosa cell death induced by $\mathrm{H}_{2} \mathrm{O}_{2}$, Puma was 
overexpressed by using a retroviral vector (Figure 3A). Overexpression (OE) of Puma dramatically increased the cleavage of caspase 3 (Figure 3A). However, Bax and Bak protein levels were unchanged (Figure 3A). Consistent with this results, after 2 days infection, overexpression of Puma significantly increased cell death from $6.4 \%$ in control group to $46.6 \%$, indicating Puma OE induces a 5.3fold increase in cell death (Figure 3B). To further confirm the role of Puma in granulosa cell death, lentiviral shRNA was used to suppress Puma expression. Consistently, $\mathrm{H}_{2} \mathrm{O}_{2}$ increased Puma protein (Figure 3C). This effect was significantly inhibited by Puma knockdown (Figure 3C). Caspase 3 activation was also inhibited in $\mathrm{H}_{2} \mathrm{O}_{2} / \mathrm{Puma}$ double knockdown (DKD) cells compared to $\mathrm{H}_{2} \mathrm{O}_{2}$ treatment alone (Figure 3D). Following Puma knockdown, $56.9 \pm 4.2 \%$ of the cells were PI staining positive. In the $\mathrm{H}_{2} \mathrm{O}_{2}$ /Puma DKD group, only $32.7 \pm 1.8 \%(P<0.01$ compared to $\mathrm{H}_{2} \mathrm{O}_{2}$ alone) took up the PI stain indicative of a $42 \%$ increase in cell viability (Figure 3D). Collectively, these findings show that Puma up-regulation contributes to apoptotic cell death induced by $\mathrm{H}_{2} \mathrm{O}_{2}$ in ovarian granulosa cells.

\section{Effect of Bcl-xL in $\mathrm{H}_{2} \mathrm{O}_{2}$-induced granulosa cell death}

The results described above showed that $\mathrm{H}_{2} \mathrm{O}_{2}$ induced a decrease in protein levels of anti-apoptotic molecules such as Bcl-2, Bcl-xL and Mcl-1. To determine whether increasing $\mathrm{Bcl}-\mathrm{xL}$ expression can inhibits $\mathrm{H}_{2} \mathrm{O}_{2}$ induced cell death, Bcl-xL was overexpressed in COV434 cells (Figure 4A) The results showed that Bcl-xL OE prevented caspase 3 activation and inhibited an increase in cleaved caspase 3 protein induced by $\mathrm{H}_{2} \mathrm{O}_{2}$ treatment (Figure 4B). Bcl-xL OE also decreased $\mathrm{H}_{2} \mathrm{O}_{2}$-induced cell death. Following Bcl-xL OE, the PI stain positive cells decreased from $59.0 \pm 3.8 \%$ in $\mathrm{H}_{2} \mathrm{O}_{2}$ treatment cells to $29.8 \pm 2.7 \%(P<0.01)$ in $\mathrm{H}_{2} \mathrm{O}_{2} / \mathrm{Bcl}-\mathrm{xL} \mathrm{OE}$ cells on day 2 (Figure $4 \mathrm{C}$ ). Bcl-2 OE also inhibited $\mathrm{H}_{2} \mathrm{O}_{2}$-induced cell death (Figure 4C).
A

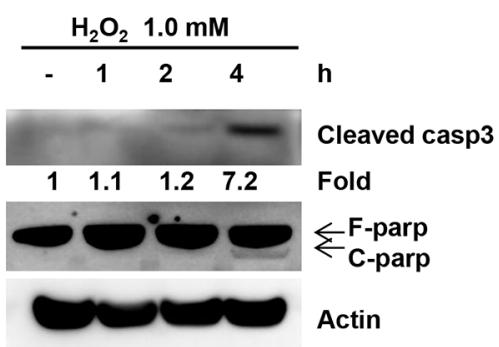

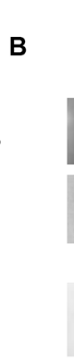

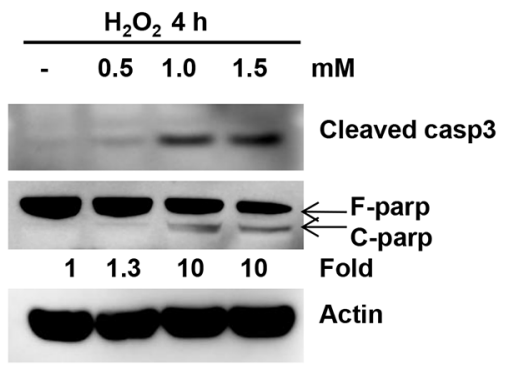

C

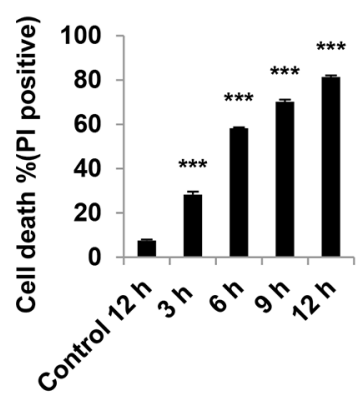

D

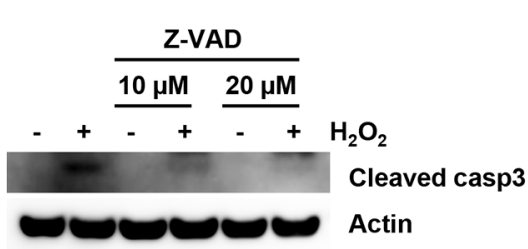

E

Control

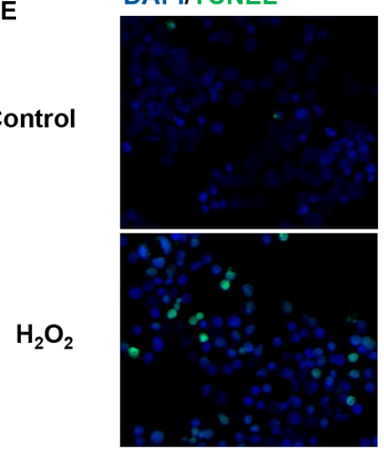

DAPI/TUNEL

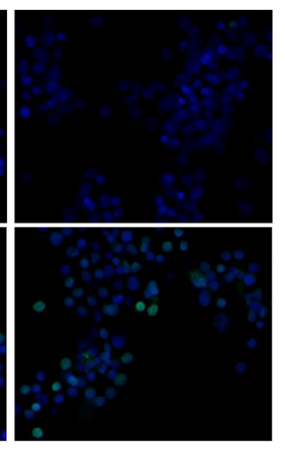

\section{$\mathbf{F}$}

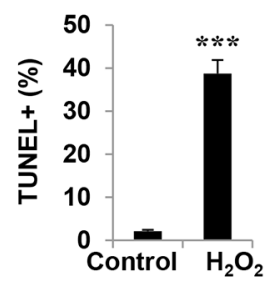

Figure 1: $\mathrm{H}_{2} \mathrm{O}_{2}$ induces cell death in human granulosa cells. (A) Caspase 3 and PARP protein levels in COV434 cells treated with $\mathrm{H}_{2} \mathrm{O}_{2}$ for different time. COV434 cells were treated with $1.0 \mathrm{mM} \mathrm{H}_{2} \mathrm{O}_{2}$ for a different time. Then cleaved caspase 3 and PARP protein were assayed by western blot. The number depicts the relative changes in the levels of the indicated proteins using densitometry analysis of the Western blots in Figure 1A. (B) Caspase3 and PARP protein levels in COV434 cells treated with $\mathrm{H}_{2} \mathrm{O}_{2}$ at the different dose for 4 hours. COV434 cells were treated with $\mathrm{H}_{2} \mathrm{O}_{2}$ at $0.5,1.0$ and $1.5 \mathrm{mM}$ for 4 hours. Then cleaved caspase 3 and PARP protein were assayed by western blot. The number depicts the relative changes in the levels of the indicated proteins using densitometry analysis of the Western blots in Figure 1B. (C) Cell death was determined by PI-staining in COV434 cells. After treatment with $1.5 \mathrm{mM} \mathrm{H}_{2} \mathrm{O}_{2}$ for different time, the percentage of cell death was shown. (D) Z-VAD, caspase inhibitor, inhibits caspase 3 cleavage. COV434 cells were treated with caspase inhibitor, 10 and $20 \mu \mathrm{M} \mathrm{Z-VAD}$, for 2 hours prior to $1.0 \mathrm{mM} \mathrm{H}_{2} \mathrm{O}_{2}$ treatment for 4 hours. Cleaved caspase 3 protein levels were determined by western blot. (E) TUNEL labeling of COV434 cells. 10 hours after $1.0 \mathrm{mM} \mathrm{H}_{2} \mathrm{O}_{2}$ treatment, apoptotic cells were assayed by TUNEL staining. (F) Quantitative TUNEL data are shown. $* * * \mathrm{P}<0.001$ compared to control group. Values are mean $\pm \mathrm{SEM}$. 


\section{$\mathrm{H}_{2} \mathrm{O}_{2}$ induced intracellular ROS production in granulosa cells}

To determine whether exogenous $\mathrm{H}_{2} \mathrm{O}_{2}$ increases intracellular ROS production, intracellular ROS production was measured by $\mathrm{H} 2 \mathrm{DCFDA}$. Indeed, $\mathrm{H}_{2} \mathrm{O}_{2}$ induced an increase in intracellular ROS production at $1 \mathrm{~h}$ in COV434 cells (Figure 5A). $1.5 \mathrm{mM} \mathrm{H}_{2} \mathrm{O}_{2}$ significantly increased ROS production by $50 \%$ at $1 \mathrm{~h}(\mathrm{P}<0.001$, Figure 5B). However, $\mathrm{H}_{2} \mathrm{O}_{2}$ significantly decreased ROS production after $1 \mathrm{~h}$ treatment $(\mathrm{P}<0.001$, Figure $5 \mathrm{~A}$ and $5 \mathrm{~B})$. For example, ROS production was decreased by $60 \%$ after $\mathrm{H}_{2} \mathrm{O}_{2}$ treatment at $6 \mathrm{~h}(\mathrm{P}<0.001$, Figure 5B). To further determine intracellular ROS production, $\mathrm{COV} 434$ cells were treated with different dose of $\mathrm{H}_{2} \mathrm{O}_{2}$ at $1 \mathrm{~h}$.
The results showed that $\mathrm{H}_{2} \mathrm{O}_{2}$ dose-dependently induced an increase in ROS production in cells (Figure 5C). 1.0 $\mathrm{mM} \mathrm{H}_{2} \mathrm{O}_{2}$ significantly increased ROS production by 1.8 fold at $1 \mathrm{~h}(\mathrm{P}<0.001$, Figure 5D). Since the Keap1-Nrf2 pathway is the key regulator of protective responses to ROS, the Keap1 and Nrf2 protein levels in COV434 cells were determined after $\mathrm{H}_{2} \mathrm{O}_{2}$ treatment. After $4 \mathrm{~h}$ treatment, 0.5 and $1.0 \mathrm{mM} \mathrm{H}_{2} \mathrm{O}_{2}$ significantly increased $\mathrm{Nrf} 2$ protein levels but $1.5 \mathrm{mM} \mathrm{H}_{2} \mathrm{O}_{2}$ induced a decrease in its protein levels. Keap 1 was only slightly decreased after $1.0 \mathrm{mM}$ $\mathrm{H}_{2} \mathrm{O}_{2}$ treatment (Figure 5E). Moreover, $0.5 \mathrm{mM} \mathrm{H}_{2} \mathrm{O}_{2}$ time-dependently induced an increase in $\mathrm{Nrf2}$ protein levels and has no effect on Keap1 (Figure 5F). Together with the above results, we conclude that $\mathrm{H}_{2} \mathrm{O}_{2}$ induces intracellular ROS production in a dose-dependent manner
A

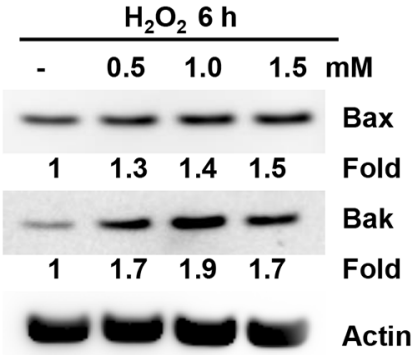

D

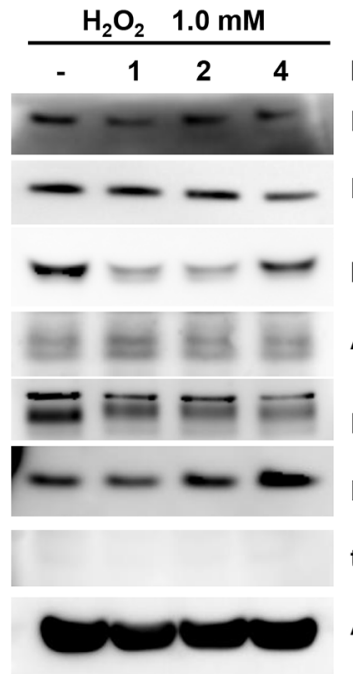

tBid

Actin

Bcl-2
Bcl-xL
Mcl-1
A1
Bim EL
Puma
tBid
Actin

B

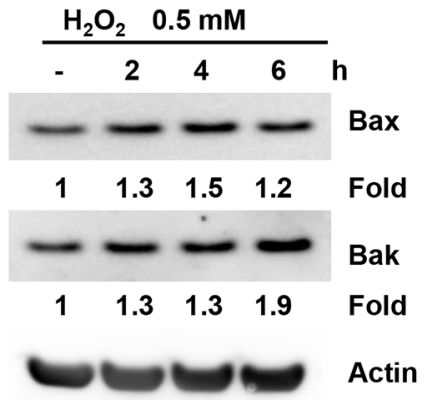

Actin
C

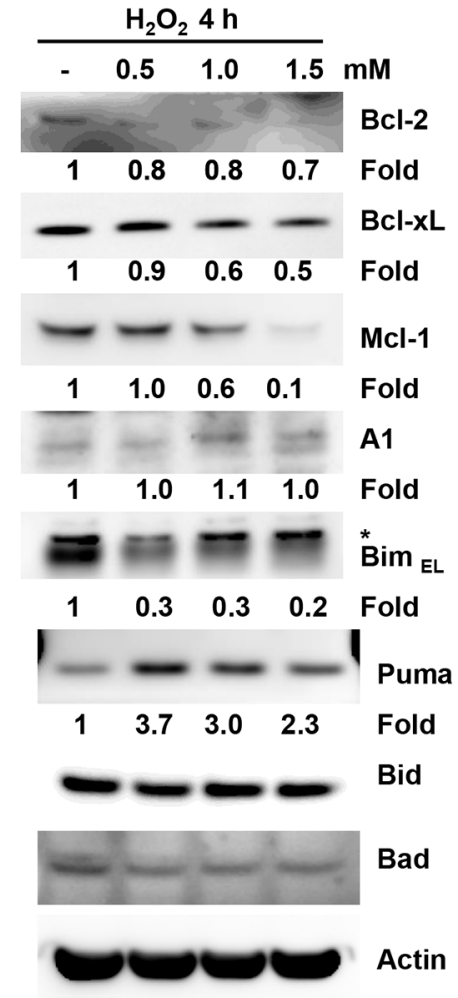

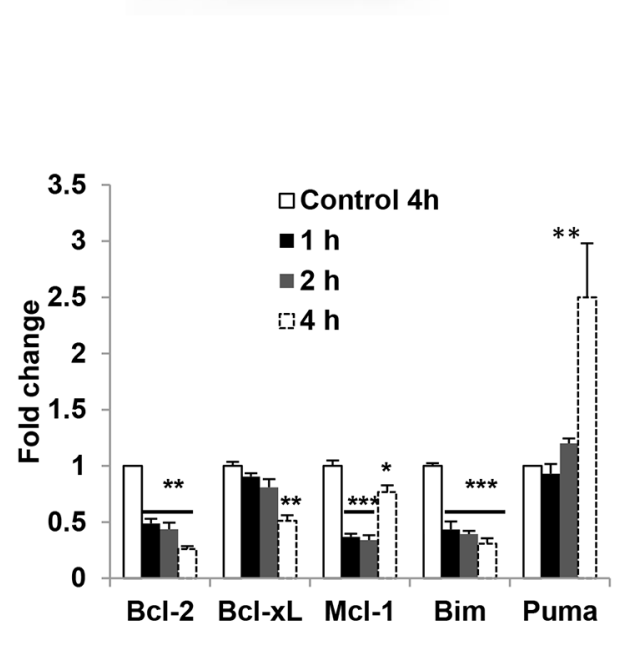

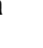


at the earlier stage, and lower dosage of $\mathrm{H}_{2} \mathrm{O}_{2}$ also induces an increase in Nrf2 protein.

\section{$\mathrm{H}_{2} \mathrm{O}_{2}$ induces $\mathrm{JNK}$ activation in granulosa cells}

To define the cell signaling pathway mediating the cell death induced by $\mathrm{H}_{2} \mathrm{O}_{2}$, JNK activation was determined in COV434 cells after $\mathrm{H}_{2} \mathrm{O}_{2}$ treatment. Phosphorylation of JNK was rapidly increased following treatment with $1.5 \mathrm{mM} \mathrm{H}_{2} \mathrm{O}_{2}$ for $1 \mathrm{~h}$ (Figure 6A). But after longer time treatment with $\mathrm{H}_{2} \mathrm{O}_{2}, \mathrm{JNK}$ activation was gradually deceased to baseline (Figure 6A). Then, SP600125, a JNK inhibitor, was used to determine the role of $\mathrm{JNK}$ in $\mathrm{H}_{2} \mathrm{O}_{2}$-induced cell death. The results showed that SP600125 inhibited phosphorylation of JNK and caspase 3 activation (Figure 6B). Consistent with the results above, SP600125 at $10 \mu \mathrm{M}$ significantly inhibited the granulosa cell death induced by $\mathrm{H}_{2} \mathrm{O}_{2} \quad(\mathrm{P}<0.05$, Figure $6 \mathrm{C}$ ). Collectively, these findings show that JNK is activated by $\mathrm{H}_{2} \mathrm{O}_{2}$ in granulosa cells.

\section{$\mathrm{H}_{2} \mathrm{O}_{2}$ triggers activation and accumulation of p53}

We next determined the consequences of ROS production in COV434 cells with $\mathrm{H}_{2} \mathrm{O}_{2}$ treatment. ROS can cause DNA damage resulting in p53 activation.
Thus p53 activation was determined in granulosa cells. Indeed, $\mathrm{H}_{2} \mathrm{O}_{2}$ at $1.5 \mathrm{mM}$ induced the highest expression of p53 at $6 \mathrm{~h}$ (Figure 7A). Phosphorylation of p53 on Ser15 (pS15-p53) following $1.5 \mathrm{mM} \mathrm{H}_{2} \mathrm{O}_{2}$ treatment was in a time-dependent manner in COV434 cells (Figure 7B). JNK has been reported to be implicated in p53 accumulation [11]. Thus the effect of JNK on p53 was determined by JNK inhibitor. SP600125 inhibited phophorylation of p53 and p53 accumulation (Figure 7C). In addition, SP600125 also inhibited Puma up-regulation induced by $\mathrm{H}_{2} \mathrm{O}_{2}$ (Figure $7 \mathrm{C}$ ). These results suggest that JNK initiates p53 accumulation and activation after $\mathrm{H}_{2} \mathrm{O}_{2}$ treatment in ovarian granulosa cells.

\section{Antioxidant NAC prevents generation of ROS induced by $\mathrm{H}_{2} \mathrm{O}_{2}$ in granulosa cells}

Next, we addressed the question whether generation of ROS induced by $\mathrm{H}_{2} \mathrm{O}_{2}$ can be prevented by ROS scavenger $N$-Acetyl-L-cysteine (NAC). We found that antioxidant $\mathrm{NAC}$ at $5 \mathrm{mM}$ prevented the generation of ROS induced by $\mathrm{H}_{2} \mathrm{O}_{2}$ (Figure 8A). Following NAC and $\mathrm{H}_{2} \mathrm{O}_{2}$ treatment, the generation of ROS decreased from 2.4-fold in $\mathrm{H}_{2} \mathrm{O}_{2}$ treatment cells to 1.2 -fold $(P<0.001)$ in $\mathrm{NAC} / \mathrm{H}_{2} \mathrm{O}_{2}$ cells (Figure $8 \mathrm{~B}$ ). These results indicate that the generation of ROS is totally blocked by NAC.
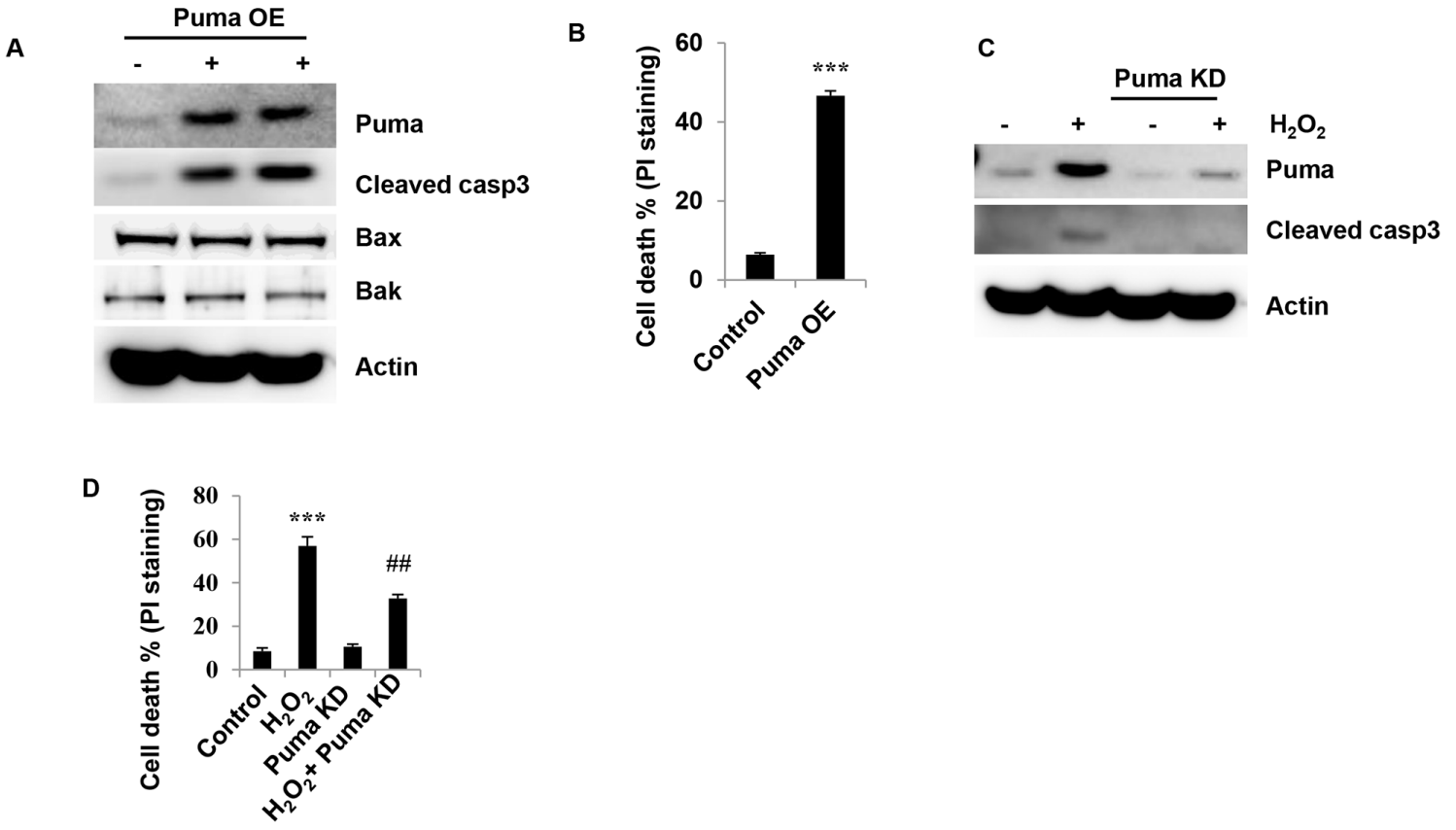

Figure 3: BH3-only molecule Puma mediates $\mathrm{H}_{2} \mathrm{O}_{2}$-induced granulosa cell death. (A) Western blot of Puma in COV434 cells. 2 days after Puma overexpression (OE) in COV434 cells, immunoblot of cleaved caspase 3 and Puma proteins in COV434 cells. (B) Cell death was determined by PI-staining in Puma OE COV434 cells. The percentage of cell death was shown. (C) Western blot of Puma and cleaved caspase 3 in COV434 cells. 2 days after Puma knockdown (KD), COV434 cells were treated with $1.5 \mathrm{mM} \mathrm{H}_{2} \mathrm{O}_{2}$ for 6 hours. Then immunoblot analysis was performed to determine Puma and cleaved caspase 3 protein levels in COV434 cells. (D) Measurement of Cell death. 2 days after Puma knockdown (KD), COV434 cells were treated with $1.5 \mathrm{mM} \mathrm{H}_{2} \mathrm{O}_{2}$ for 6 hours, cell death was determined by PIstaining $(\mathrm{n}=3)$. $* * * \mathrm{P}<0.001$ compared to control group. \#\#P<0.01 compared to $\mathrm{H}_{2} \mathrm{O}_{2}$ group. 


\section{Antioxidant NAC prevents ROS-mediated JNK activation and p53 accumulation in granulosa cells}

The above results demonstrate that JNK and $\mathrm{p} 53$ are involved in $\mathrm{H}_{2} \mathrm{O}_{2}$-induced cell death. Thus, we speculated that NAC might prevent a ROS-JNK-p53 cycle to protect granulosa cells from cell death triggered by $\mathrm{H}_{2} \mathrm{O}_{2}$. The results showed that even at $5 \mathrm{mM}$ NAC efficiently prevented caspase 3 activation (Figure 9A and 9B). NAC at $5 \mathrm{mM}$ also obviously reduced phosphorylation of p53 and p53 accumulation, indicating that ROS was involved in p53 accumulation (Figure 9B). Consistently, NAC obviously reversed the activation of JNK and inhibited Puma up-regulation (Figure 9C), suggesting that JNK was a critical player downstream of ROS in the signal pathway leading to p53 activation. Moreover, NAC fully rescued the cell death induced by $\mathrm{H}_{2} \mathrm{O}_{2}$ (Figure 9D). The cell death decreased from $51 \%$ in $\mathrm{H}_{2} \mathrm{O}_{2}$ treatment cells to $14.5 \%$ in $\mathrm{NAC} / \mathrm{H}_{2} \mathrm{O}_{2}$ treatment cells $(\mathrm{P}<0.001$, Figure 9D). Figure 9E shows the model of $\mathrm{H}_{2} \mathrm{O}_{2}$-inducedgranulosa cell death. Exogenous $\mathrm{H}_{2} \mathrm{O}_{2}$ increases the generation of intracellular ROS in granulosa cells. The accumulation of ROS leads to activation of JNK. Activated JNK facilitatses

A
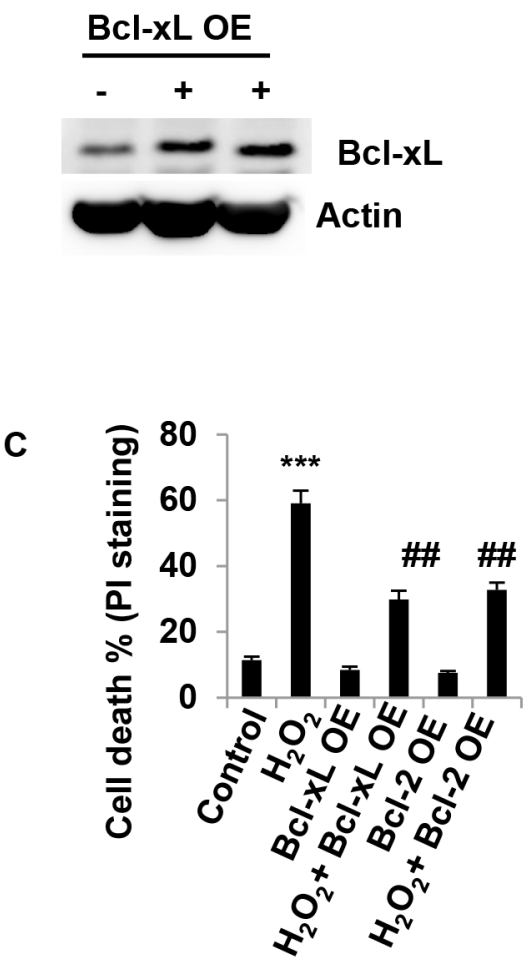

p53 activation and accumulation. p53 upregulates Puma, which induces Bax and Bak activation and leads to the robust apoptosis. Suppression of Bcl-2, Bcl-xL and Mcl-1 also results in apoptosis.

All these results demonstrated that ROS-JNK-p53 pathway plays a key role in regulating cell death in $\mathrm{H}_{2} \mathrm{O}_{2}$ treated COV434 cells, and antioxidant NAC prevents ROS-mediated JNK activation and p53 accumulation in ovarian granulosa cells.

\section{DISCUSSION}

Preovulatory as well as ovulated oocytes are encircled with several layers of cumulus and mural granulosa cells which constitute the largest group of cells in the ovary and play a crucial role in follicle development and oocyte competence. Physiologic function of granulosa cell is dependent on paracrine and autocrine cytokines in ovarian microenvironment and reproductive hormones in peripheral blood [12]. The reduced number of granulosa cells and disruption in the cell-cell communication might have deprived oocyte of nutrients and survival factors inside the preovulatory follicle and induced apoptosis in ovulated oocytes. Human ovaries produce a constant

B

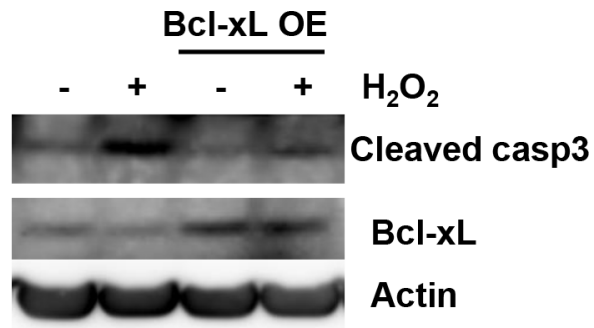

Figure 4: Overexpression of anti-apoptotic molecule Bcl-xL inhibits $\mathrm{H}_{2} \mathrm{O}_{2}$-induced granulosa cell death. (A) Western blot of Bcl-xL in COV434 cells. 2 days after Bcl-xL overexpression (OE) in COV434 cells, immunoblot of Bcl-xL proteins in COV434 cells. (B) Western blot of Bcl-xL and cleaved caspase3 in COV434 cells. 2 days after Bcl-xL OE, COV434 cells were treated with $1.5 \mathrm{mM}$ $\mathrm{H}_{2} \mathrm{O}_{2}$ for 6 hours. Then immunoblot analysis was performed to determine Bcl-xL and cleaved caspase3 protein levels in COV434 cells. (C) Measurement of Cell death. 2 days after Bcl-xL OE, COV434 cells were treated with $1.5 \mathrm{mM} \mathrm{H}_{2} \mathrm{O}_{2}$ for 6 hours, cell death was determined by PI-staining $(\mathrm{n}=3)$. $* * * \mathrm{P}<0.001$ compared to control group. $\# \# \mathrm{P}<0.01$ compared to $\mathrm{H}_{2} \mathrm{O}_{2}$ group. Values are mean $\pm \mathrm{SEM}$. 
number of oocytes during every menstrual cycle. However, the majority of follicles undergo atresia, which is mediated by apoptosis [13]. A progressive reduction in granulosa cells is a key element in the development of antral follicle atresia. The apoptosis of granulosa cells leads to follicular atresia due to the insufficiency of survival signals and/or physiologic/nonphysiologic apoptotic signals [14].

Apoptosis can be triggered by various stimuli from outside or inside the cells. It has also been suggested that the age-related decline in oocyte quality and fertility is modulated by oxidative stress [15]. Oxidative stress also contributes to granulosa cell apoptosis [16]. Therefore protecting granulosa cells against oxidative stress-induced apoptosis might be of great therapeutic value in the treatment of reproductive ageing. Data of the present study suggest that $\mathrm{H}_{2} \mathrm{O}_{2}$ increased the granulosa cell death in a dose- and time-dependent manner. Caspase 3 activation, PARP cleavage and TUNEL positive staining were increased after $\mathrm{H}_{2} \mathrm{O}_{2}$ treatment. Z-VAD almost completely inhibited caspase 3 cleavage. These results suggest that $\mathrm{H}_{2} \mathrm{O}_{2}$ can induce apoptosis in ovarian granulosa cells, which was consistent with the previous studies [17]. Since Bcl-2 family proteins are the major regulators of apoptosis, we determine how Bcl-2 family members are involved in granulosa cell apoptosis induced by $\mathrm{H}_{2} \mathrm{O}_{2}$. The results showed that $\mathrm{H}_{2} \mathrm{O}_{2}$ decreased anti-apoptotic molecules $\mathrm{Bcl}-2, \mathrm{Bcl}-\mathrm{xL}$ and $\mathrm{Mcl}-1$, and increased pro-apoptotic molecules such as Bax, Bak and Puma. To further confirm that Puma was a player in granulosa cell apoptosis, the effect of overexpression of Puma on granulosa cells was determined. Indeed, the results showed that overexpression of Puma induced COV434 cell apoptosis. In contrast, Puma KD significantly decreased the cell apoptosis induced by $\mathrm{H}_{2} \mathrm{O}_{2}$. On the other hand, overexpression of the Bcl-xL inhibited $\mathrm{H}_{2} \mathrm{O}_{2}$-induced granulosa cell apoptosis. Due to the BH3-only molecule Puma directly inducing a stepwise activation of Bax and Bak, increasing Puma would results in granulosa cell apoptosis. Furthermore, autoactivation of Bax and Bak can occur independently of activator $\mathrm{BH} 3 \mathrm{~s}$ through downregulation of $\mathrm{Bcl}-2$, Bcl$\mathrm{xL}$ and Mcl-1 [18]. Therefore, $\mathrm{H}_{2} \mathrm{O}_{2}$-induced granulosa cell apoptosis was mediated by Bax and Bak activation through both increasing Puma and decreasing antiapoptotic molecules Bcl-2, Bcl-xL and Mcl-1.

Although ROS play a role in many cellular processes, high levels of ROS can induce cellular damage
A

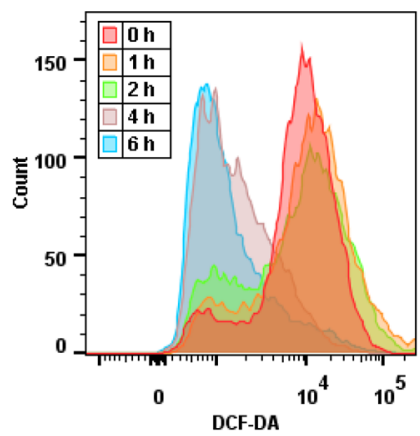

D

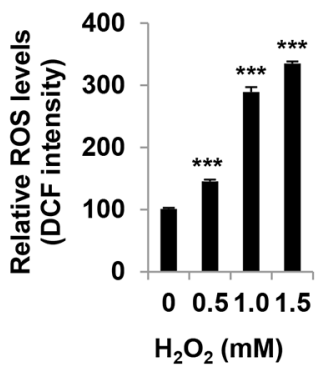

B

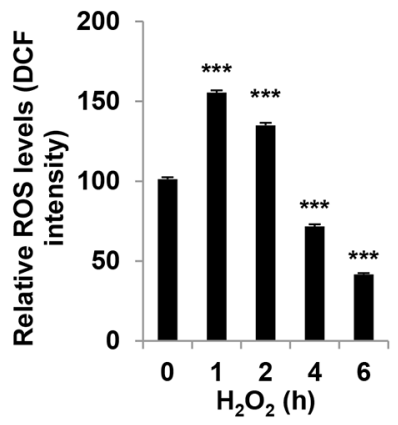

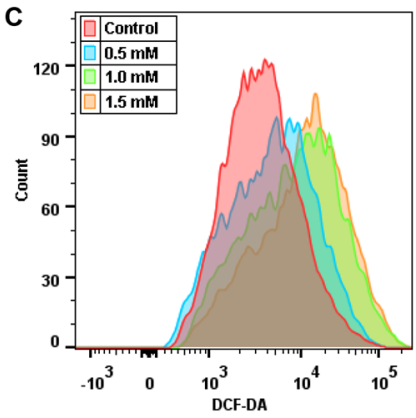

E

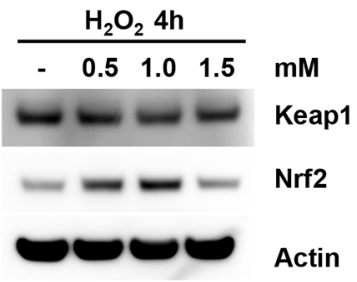

$\mathbf{F}$

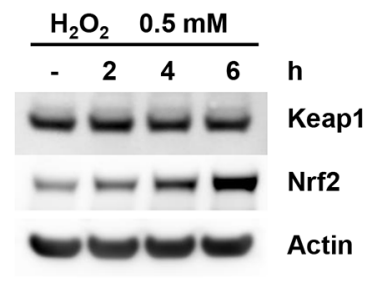

Figure 5: $\mathrm{H}_{2} \mathrm{O}_{2}$ induces the generation of intracellular ROS in granulosa cells. (A+B) The effect of $\mathrm{H}_{2} \mathrm{O}_{2}$ on the intracellular ROS level was determined by flow cytometry analysis. COV434 cell were incubated with $1.5 \mathrm{mM} \mathrm{H}_{2} \mathrm{O}_{2}$ for different time, the intracellular ROS level was determined by flow cytometry analysis (A). The results were shown as relative value after compared to control group of mean fluorescence (B). (C+D) The effect of $\mathrm{H}_{2} \mathrm{O}_{2}$ on the intracellular ROS level was determined by flow cytometry analysis. COV434 cell were incubated with $\mathrm{H}_{2} \mathrm{O}_{2}$ at different concentration for 1 hour, the intracellular ROS level was determined by flow cytometry analysis (C). The results were shown as relative value after compared to control group of mean fluorescence (D). Western blot of Keap1 and Nrf2 in COV434 cells. 4 hours after $\mathrm{H}_{2} \mathrm{O}_{2}$ treatment at $0.5,1.0$ and $1.5 \mathrm{mM}$ in COV434 cells (E) or the cells were treated with $0.5 \mathrm{mM} \mathrm{H}_{2} \mathrm{O}_{2}$ for different time (F), immunoblot analysis was performed to determine Keap1 and Nrf2 protein levels in COV434 cells. $* * * \mathrm{P}<0.001$ compared to control group. Values are mean \pm SEM. 
such as DNA damage, polyunsaturated fatty acids and amino acids oxidations, and specific enzymes deactivation by oxidation of co-factors. To further identify the mechanisms of granulosa cell death induced by $\mathrm{H}_{2} \mathrm{O}_{2}$, we determined the generation of intracellular ROS. Exogenous $\mathrm{H}_{2} \mathrm{O}_{2}$ dose-dependently increased the generation of intracellular ROS at the earlier time point. After 4 hours treatment with exogenous $\mathrm{H}_{2} \mathrm{O}_{2}$, the generation of ROS was reduced. One explanation is that higher ROS generated at the earlier time damages the cell membrane, which leads to the leak of fluorescent DCF. Thus fluorescence is lower at later time after $\mathrm{H}_{2} \mathrm{O}_{2}$ treatment. Another explanation is that cells use defense mechanisms to ameliorate the ROS. Indeed, here we showed that after $\mathrm{H}_{2} \mathrm{O}_{2}$ treatment, although Keap1 only slightly decreased, Nrf2 significantly increased. Keap1 serves as the substrate adaptor subunit in the E3 holoenzyme in the ubiquitination pathway, leading to $\mathrm{Nrf} 2$ ubiquitination and degradation. $\mathrm{H}_{2} \mathrm{O}_{2}$
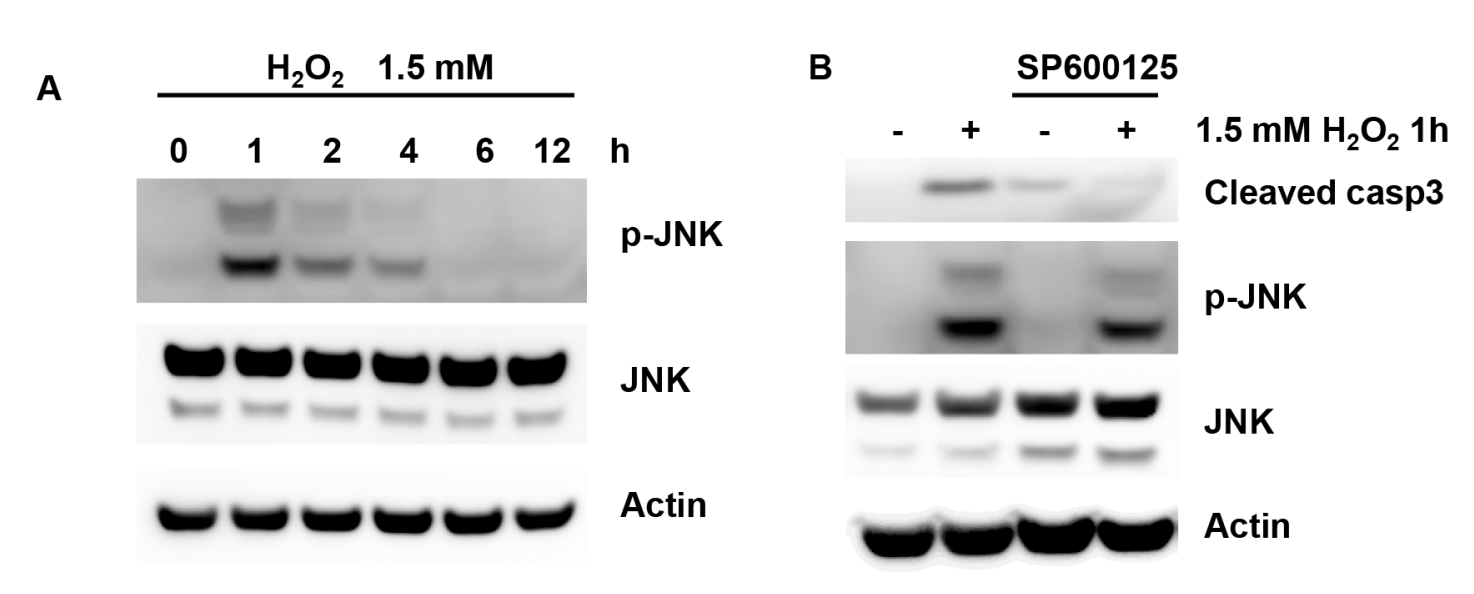

can cause Keap1 oxidation, leading to a conformational change of Keap1. Such conformational alterations inhibit the binding between Nrf2 and Keap1, thus stopping Nrf2 ubiquitination and degradation [19]. Ultimately, Nrf2 translocates to the nuclear and regulates the expressions of antioxidants [20]. Therefore we assume that the increase in $\mathrm{Nrf} 2$ is the protective response of granulosa cells to ROSinduced stress. Moreover, in the present study, anti-oxidant NAC efficiently protects COV434 cells against cell death induced by ROS. As a synthetic precursor of intracellular cysteine and glutathione, the anti-ROS activity of NAC results from its free radical scavenging property either directly via the redox potential of thiols, or secondarily via increasing glutathione levels in the cells [21].

It has been well established that JNK, a member of the mitogen-activated protein kinases(MAPKs) pathway, plays a critical role in both extrinsic and intrinsic apoptotic pathway [22]. To determine the mechanism by which

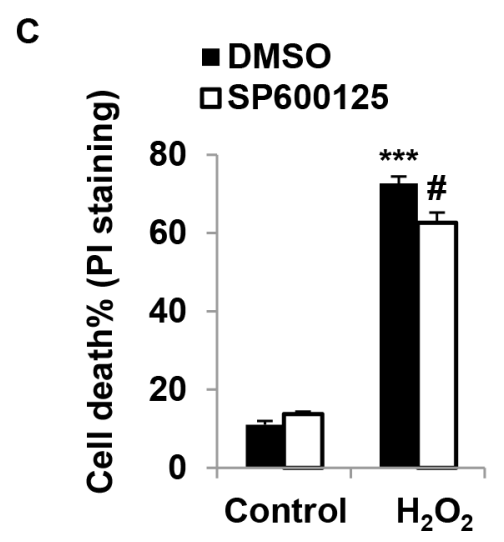

Figure 6: $\mathrm{H}_{2} \mathrm{O}_{2}$ induces $\mathrm{H}_{2} \mathrm{O}_{2}$ induces $\mathbf{J N K}$ activation in granulosa cells. (A) Effect of $\mathrm{H}_{2} \mathrm{O}_{2}$ on the JNK in COV434 cells. COV434 cell were incubated with $1.5 \mathrm{mM} \mathrm{H}_{2} \mathrm{O}_{2}$ for different time, the phosphorylation of JNK was determined by western blot. (B) Effect of SP600125 on the JNK activation was determined by western blot. COV434 cell were incubated with $10 \mu \mathrm{M}$ SP600125 for 3 hours, then $1.5 \mathrm{mM} \mathrm{H}_{2} \mathrm{O}_{2}$ was added to the medicum for 1 hour. JNK activation was determined by western blot. (C) Effect of SP600125 on the cell death induced by $\mathrm{H}_{2} \mathrm{O}_{2}$. COV434 cell were incubated with $10 \mu \mathrm{M} \mathrm{SP} 600125$ for 3 hours, then $1.5 \mathrm{mM} \mathrm{H}_{2} \mathrm{O}_{2}$ was added to the medicum for 6 hours. JNK activation was determined by western blot. Cell death was determined by PI-staining $(\mathrm{n}=3)$. ***P $<0.001$ compared to control group. $\# \mathrm{P}<0.05$ compared to $\mathrm{H}_{2} \mathrm{O}_{2}$ alone group. 
A

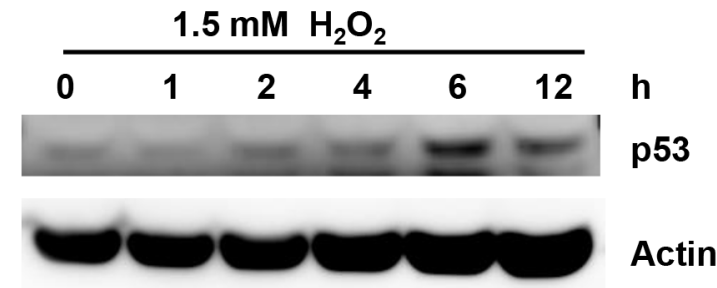

C

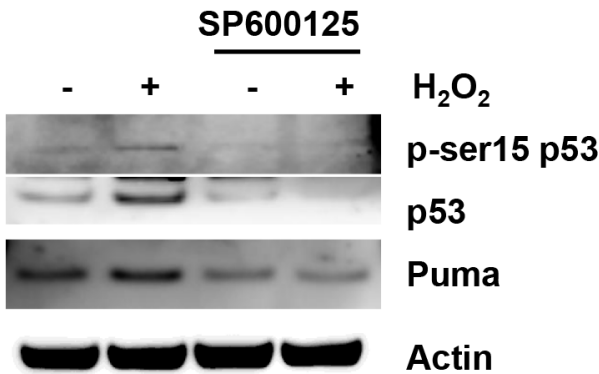

B

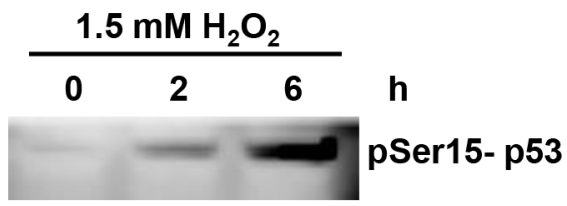

Actin

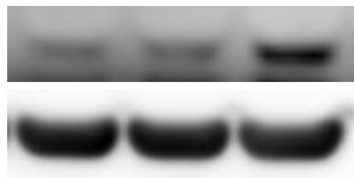

p53

Actin

Figure 7: $\mathrm{H}_{2} \mathrm{O}_{2}$ induces p53 accumulation associated with JNK activation. (A) Effect of $\mathrm{H}_{2} \mathrm{O}_{2}$ on the p53 in COV434 cells. COV434 cell were incubated with $1.5 \mathrm{mM} \mathrm{H}_{2} \mathrm{O}_{2}$ for different time, the protein lelves of p53 was determined by western blot. (B) Effect of $\mathrm{H}_{2} \mathrm{O}_{2}$ on the p53 activation in COV434 cells. COV434 cell were incubated with $1.5 \mathrm{mM} \mathrm{H}_{2} \mathrm{O}_{2}$ for 2 and 6 hours, the phosphorylatio of p53 and p53 were determined by western blot. (C) Effect of SP600125 on p53 activation and accumulation induced by $\mathrm{H}_{2} \mathrm{O}_{2}$. COV434 cell were incubated with $20 \mu \mathrm{M}$ SP600125 for 3 hours, then $1.5 \mathrm{mM} \mathrm{H}_{2} \mathrm{O}_{2}$ was added to the medicum for 4 hours. p53 activation was determined by western blot.

A

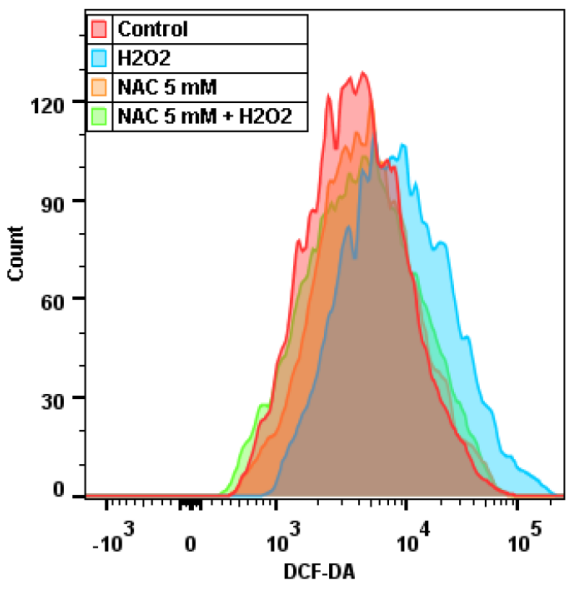

B

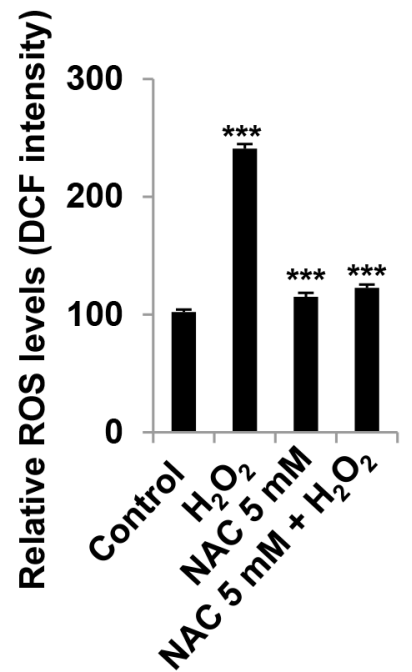

Figure 8: NAC prevents generation of ROS induced by $\mathbf{H}_{2} \mathrm{O}_{2}$ in granulosa cells. (A+B) Effect of anti-oxidant NAC on the generation of ROS induced by $\mathrm{H}_{2} \mathrm{O}_{2}$ in COV434 cells. COV434 cell were incubated with $5 \mathrm{mM} \mathrm{NAC}$ for 1 hour prior to $1.5 \mathrm{mM} \mathrm{H}_{2} \mathrm{O}_{2}$ treatment for 1 hour. The intracellular ROS level was determined by flow cytometry analysis (A). The results were shown as relative value after compared to control group of mean fluorescence (B). ${ }^{* *} \mathrm{P}<0.001$ compared to control group. Values are mean $\pm \mathrm{SEM}$.

increased ROS cause cell death, the effect of JNK on cell death was investigated. Here we found that $\mathrm{H}_{2} \mathrm{O}_{2}$ induced JNK phosphorylation (p-JNK) at the earlier time point, which was consistent with the increased ROS levels at that time. Importantly, p-JNK induction was due to the increased ROS, since NAC inhibited JNK activation. Notably, JNK serves as a critical mediator of the $\mathrm{H}_{2} \mathrm{O}_{2}$ induced apoptosis, as also evidenced by the inhibition 
of caspase 3 cleavage and cell death by JNK inhibitor SP600125.

In response to DNA damage induced by oxidative stress, wild-type p53 orchestrates transcriptions of numerous genes and induces cells either to cell cycle arrest, senescence, or apoptosis via differential activation of target genes, preventing the propagation of damaged DNA [23]. Our studies showed that $\mathrm{H}_{2} \mathrm{O}_{2}$ induced an increase in phosphorylation of p53 and p53 accumulation. JNK inhibitor SP600125 inhibited the activation and accumulation of p53, indicating that p53 induction is due to JNK activation. p53 can also trigger cell apoptosis by directly activating Bax or by upregulating Puma to indirectly activate Bax and Bak. On the other hand, NAC fully reversed the apoptosis triggered by $\mathrm{H}_{2} \mathrm{O}_{2}$ and inhibited the activation of JNK and p53 accumulation.
These data further confirmed that ROS was involved in the activation of JNK and accumulation of p53.

In conclusion, exogenous $\mathrm{H}_{2} \mathrm{O}_{2}$ dose- and timedependently increased granulosa cell apoptosis which related to inducing a decrease in anti-apoptotic members such as Bcl-2, Bcl-xL and Mcl-1, and an increase in BH3-only molecule Puma. Exogenous $\mathrm{H}_{2} \mathrm{O}_{2}$ dosedependently increased the generation of intracellular ROS at the earlier time point. $\mathrm{H}_{2} \mathrm{O}_{2}$ increases $\mathrm{Nrf} 2$ and promotes the activation of JNK and p53 accumulation via generation of ROS. Anti-oxidant NAC prevented $\mathrm{H}_{2} \mathrm{O}_{2}-$ induced cell death by deactivating JNK and inhibiting p53 accumulation through inhibiting ROS production. These results suggest antioxidant therapeutic interventions may have beneficial effects on follicular atresia associated with ovarian granulosa cell apoptosis.
A

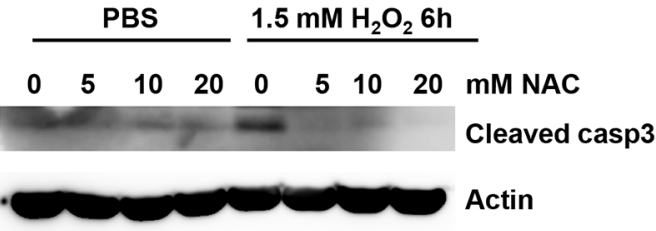

C

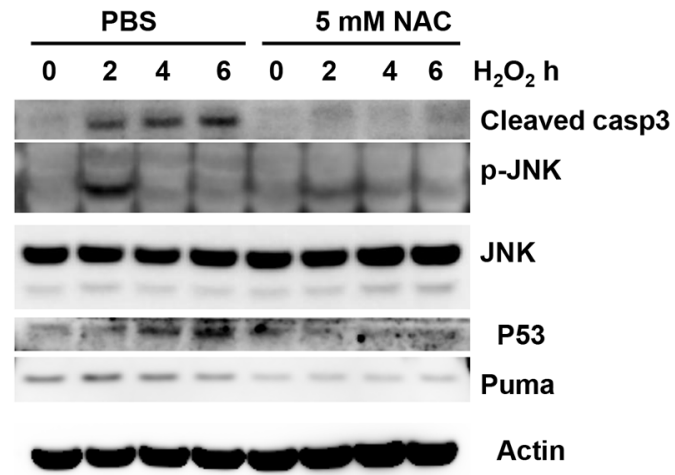

B

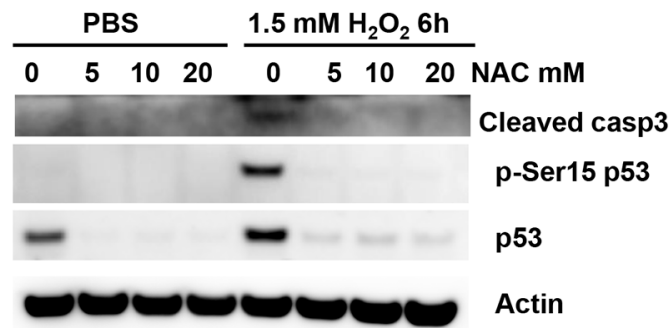

D

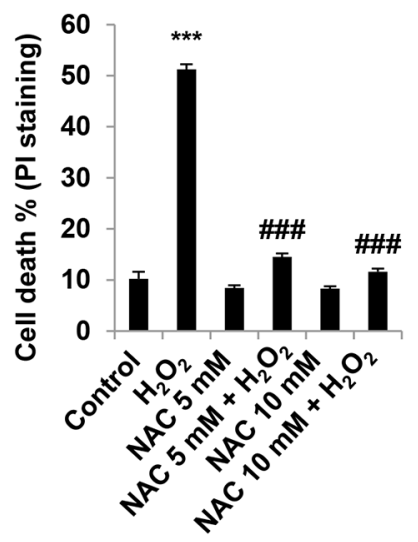

E

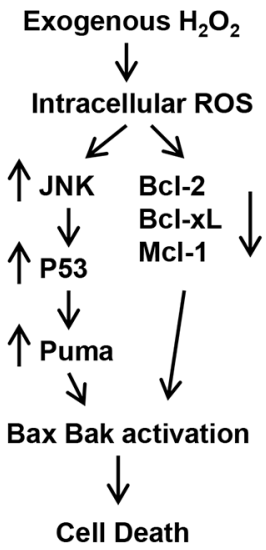

Figure 9: NAC prevents ROS-mediated JNK activation and p53 accumulation in granulosa cells. (A) Effect of antioxidant NAC on caspase 3 cleavage induced by $\mathrm{H}_{2} \mathrm{O}_{2}$ in COV434 cells. COV434 cell were incubated with NAC at different concentration for 1 hour prior to $1.5 \mathrm{mM} \mathrm{H}_{2} \mathrm{O}_{2}$ treatment for 6 hours. The cleaved capase 3 was determined by western blot. (B) Effect of anti-oxidant NAC on $\mathrm{p} 53$ activation and accumulation induced by $\mathrm{H}_{2} \mathrm{O}_{2}$ in COV434 cells. COV434 cell were incubated with NAC at different concentration for 1 hour prior to $1.5 \mathrm{mM} \mathrm{H}_{2} \mathrm{O}_{2}$ treatment for 6 hours. The phosphorylation and accumulation of p53 were determined by western blot. (C) Effect of anti-oxidant NAC on JNK activation and p53 accumulation induced by $\mathrm{H}_{2} \mathrm{O}_{2}$ in COV434 cells. COV434 cell were incubated with $5 \mathrm{mM}$ NAC for 1 hour prior to $1.0 \mathrm{mM} \mathrm{H}_{2} \mathrm{O}_{2}$ treatment for different time. The phosphorylation of JNK, p53 accumulationand Puma protein levels were determined by western blot. (D) Effect of anti-oxidant NAC on cell death induced by $\mathrm{H}_{2} \mathrm{O}_{2}$ in COV434 cells. COV434 cell were incubated with $5 \mathrm{mM} \mathrm{NAC}$ for 1 hour prior to $1.5 \mathrm{mM} \mathrm{H}_{2} \mathrm{O}_{2}$ treatment for 6 hours. Cell death was determined by PI-staining ( $\mathrm{n}=3$ ). $* * * \mathrm{P}<0.001$ compared to control group. \#\#\#P<0.001 compared to $\mathrm{H}_{2} \mathrm{O}_{2}$ alone group. (E) Model of $\mathrm{H}_{2} \mathrm{O}_{2}$-induced granulosa cell death. Exogenous $\mathrm{H}_{2} \mathrm{O}_{2}$ increases the generation of intracellular ROS in granulosa cells. The accumulation of ROS leads to activation of JNK. Activated JNK facilitatses p53 activation and accumulation. p53 upregulates Puma, which induces Bax and Bak activation and leads to the robust apoptosis. ROS - induced suppression of Bcl-2, Bcl-xL and Mcl-1 also contribute to apoptosis induction. 


\section{MATERIALS AND METHODS}

\section{COV434 cell culture}

COV434 cells were purchased from Sigma and maintained in Dulbecco's modified Eagle's medium-F12 (DMEM-F12) with GlutaMAX ${ }^{\mathrm{TM}}$ supplemented with $9 \%$ FBS, henceforth referred to as complete media, at $37^{\circ} \mathrm{C}$ in a humidified atmosphere of $95 \%$ air and $5 \% \mathrm{CO}_{2}$. During maintenance, cells were passaged every $4-5$ days. Cells from passages $25-50$ were used for the experiments reported herein. For experiments, cells were harvested by trypsinization, counted using a hemacytometer, and were plated in complete medium. For protein extraction COV434 cells were plated $5 \times 10^{6}$ cells/flask or $2 \times 10^{5}$ cells/well of 6-well plate for $\mathrm{H}_{2} \mathrm{O}_{2}$ treatment. Cells were plated $5 \times 10^{4}$ cells per chamber of eight-chamber LabTek II CC2 tissue culture slides for TUNEL and Hoechst 33342 staining.

\section{Quantitation of cell death}

Cell death was quantified by propidium iodide staining [24], followed by flow cytometric analyses using a FACS Caliber (BD Bioscience) and FlowJo software. Propidium iodide (PI) intercalates into double-stranded nucleic acids. PI is excluded by viable cells but can penetrate cell membranes of dying or dead cells. $20 \mu \mathrm{M}$ pan-caspase inhibitor benzyloxycarbonyl-Val-Ala-Aspfluoromethylketone (Z-VAD) was added to the medium 2 hours prior to treatment COV434 cells by $\mathrm{H}_{2} \mathrm{O}_{2}$. Z-VAD was added to the cells on day1.

\section{Retrovirus infection}

Mouse $\operatorname{Bim}_{\mathrm{EL}}$ and Puma were cloned into the retroviral expression vector MSCV-IRES-GFP (pMIG) (Clontech). The production of amphotropic retroviruses using the 293GPG packing cell line was performed as described previously [25]. Retroviral plasmids were transfected using X-tremeGene 9 DNA transfection reagent (Roche) according to the manufacturer's protocols. Retroviral transduction of each indicated BCL-2 family protein was confirmed by western blotting. Two days after infection with Bcl-xL retrovirus, COV434 cells were lysed and probed with antibody for immunoblot analysis.

\section{Lentivirus-mediated shRNA expression}

The pLKO.1-puro lentivirus vector was generously provided by Dr. Sheila Stewart of Washington University Medical School (St. Louis, MO). Lentiviral shRNA targets in the murine Puma mRNA were purchased from GE Dharmacon (RMM4534) and identified using western blot. Recombinant lentiviral particles were prepared by transfecting HEK $293 \mathrm{~T}$ cells with the appropriate pLKO.1-puro plasmid plus pHR'CVM8.2 delta $\mathrm{R}$ and pCMV-VSV-G plasmids. Lentivirus was added to the medium on day 1.

\section{Western blot}

COV434 cells and islets were lysed in RIPA cell lysis buffer (Thermal Scientific) containing PMSF, $\mathrm{Na}_{3} \mathrm{VO}_{4}$, and complete protease inhibitor mixture. Equal amounts of protein were resolved by $10 \%$ or $4-12 \%$ NuPAGE (Invitrogen) gels, transferred onto PVDF membrane (Immobilon-P; Millipore), and blots were probed with antibodies against Bax (N20) (SC493, Santa Cruz) and Bak (06536, Upstate), Bcl-2 (554218; Pharmigen), Bcl-xL(2762, Cell Signaling), Puma (7467; Cell Signaling Technologies), Bim (202000; Calbiochem), cleaved caspase3 (9661; Cell Signaling Technologies), phospho-JNK (Thr183/Tyr185) (4668; Cell Signaling), JNK (9258; Cell Signaling), phospho-p53 (Ser15)(12571; Cell Signaling), p53(2524; Cell Signaling), actin (A2066; Sigma). Antibody detection was accomplished using enhanced chemiluminescence method (Western Lightning, PerkinElmer) and LAS-3000 Imaging system (FUJIFILM).

\section{Detection of intracellular ROS [26]}

The intracellular levels of ROS were measured by loading the COV434 cells with the fluoroprobe H2dichlorofluorescein diacetate (H2DCF-DA) (Invitrogen). Dichlorofluorescein diacetate (DCF-DA) is taken up by cells, is cleaved to DCF by intracellular esterases, and is oxidized in the presence of ROS to DCF. The H2DCFDA probe was freshly reconstituted in DMSO before loading. In brief, cells were cultured $5 \times 10^{4}$ cells per well of 12 -well plate in $1 \mathrm{ml}$ of complete medium for $24 \mathrm{~h}$. For measurement of the effect of $\mathrm{H}_{2} \mathrm{O}_{2}$ treatment on ROS generation, the wells were washed with $\mathrm{PBS}$ after $\mathrm{H}_{2} \mathrm{O}_{2}$ treatment, loaded for $30 \mathrm{~min}$ at $37^{\circ} \mathrm{C}$ with $1 \mu \mathrm{M}$ DCF-DA in medium. Then the DCF-DA containing medium was removed, cells were washed with PBS, and maintained in PBS while fluorescence intensity was read by fluorescenceactivated cell sorting (FACS). The fluorescence intensity was analyzed and quantified using Flowjo. The results are representative of 3 independent cultures.

\section{TUNEL staining}

The terminal deoxynucleotidyltransferase-mediated dUTP nick end labeling (TUNEL) labeling used the Dead End Fluorometric TUNEL System (Promega Corp). TUNEL technique was used to detect DNA strand breaks formed during apoptosis. More than 300 cells were counted after TUNEL staining and at least 3 wells were counted per group. 


\section{Statistical analysis}

The 2-tailed unpaired Student's $t$ test was used to assess the statistical significance of differences between 2 sets of data. Differences were considered significant when $P<0.05$. In all experiments, the number of asterisks is used to designate the following levels of statistical significance: $* * * \mathrm{p}<0.001,{ }^{* *} \mathrm{p}<0.01,{ }^{*} \mathrm{p}<0.05$ compared with control group. Results are presented as mean $\pm \mathrm{SEM}$.

\section{ACKNOWLEDGMENTS}

This study was supported by the National Natural Science Fund of China (81303001).

\section{CONFLICTS OF INTEREST}

No potential conflicts of interest relevant to this article were reported.

\section{Author contributions}

D.R. and H.Y. designed research; H.Y., X.Y, Y, D. performed research; D.R. and H.Y. analyzed data, H.Y. and D.R. wrote the paper.

\section{REFERENCES}

1. Assou S, Haouzi D, De Vos J, Hamamah S. Human cumulus cells as biomarkers for embryo and pregnancy outcomes. Mol Hum Reprod. 2010; 16:531-538.

2. Adeldust H, Zeinoaldini S, Kohram H, Amiri Roudbar M, Daliri Joupari M. In vitro maturation of ovine oocyte in a modified granulosa cells co-culture system and alphatocopherol supplementation: effects on nuclear maturation and cleavage. J Anim Sci Technol. 2015; 57:27.

3. Tripathi A, Shrivastav TG, Chaube SK. An increase of granulosa cell apoptosis mediates aqueous neem (Azadirachta indica) leaf extract-induced oocyte apoptosis in rat. Int J Appl Basic Med Res. 2013; 3:27-36.

4. Guo JQ, Gao X, Lin ZJ, Wu WZ, Huang LH, Dong HY, Chen J, Lu J, Fu YF, Wang J, Ma YJ, Chen XW, Wu ZX, et al. BMSCs reduce rat granulosa cell apoptosis induced by cisplatin and perimenopause. BMC Cell Biol. 2013; 14:18.

5. Ren D, Sun J, Wang C, Ye H, Mao L, Cheng EH, Bell GI, Polonsky KS. Role of BH3-only molecules Bim and Puma in beta-cell death in Pdx1 deficiency. Diabetes. 2014; 63:2744-2750.

6. Devine PJ, Perreault SD, Luderer U. Roles of reactive oxygen species and antioxidants in ovarian toxicity. Biology of reproduction. 2012; 86:27.

7. Luderer U. Ovarian toxicity from reactive oxygen species. Vitam Horm. 2014; 94:99-127.
8. Agarwal A, Aponte-Mellado A, Premkumar BJ, Shaman A, Gupta S. The effects of oxidative stress on female reproduction: a review. Reproductive biology and endocrinology. 2012; 10:49.

9. Cortes-Wanstreet MM, Giedzinski E, Limoli CL, Luderer U. Overexpression of glutamate-cysteine ligase protects human COV434 granulosa tumour cells against oxidative and gamma-radiation-induced cell death. Mutagenesis. $2009 ; 24: 211-224$.

10. Tsai-Turton M, Luong BT, Tan Y, Luderer U. Cyclophosphamide-induced apoptosis in COV434 human granulosa cells involves oxidative stress and glutathione depletion. Toxicological sciences. 2007; 98:216-230.

11. Qi M, Zhou H, Fan S, Li Z, Yao G, Tashiro S, Onodera S, Xia M, Ikejima T. mTOR inactivation by ROS-JNK-p53 pathway plays an essential role in psedolaric acid B induced autophagy-dependent senescence in murine fibrosarcoma L929 cells. European journal of pharmacology. 2013; 715:76-88.

12. Hull KL, Harvey S. Growth hormone and reproduction: a review of endocrine and autocrine/paracrine interactions. International journal of endocrinology. 2014; 2014:234014.

13. Yu YS, Sui HS, Han ZB, Li W, Luo MJ, Tan JH. Apoptosis in granulosa cells during follicular atresia: relationship with steroids and insulin-like growth factors. Cell Res. 2004; $14: 341-346$

14. Williams CJ, Erickson GF. (2000). Morphology and Physiology of the Ovary. In: De Groot LJ, Beck-Peccoz P, Chrousos G, Dungan K, Grossman A, Hershman JM, Koch C, McLachlan R, New M, Rebar R, Singer F, Vinik A and Weickert MO, eds. Endotext. (South Dartmouth (MA).

15. Agarwal A, Gupta S, Sharma RK. Role of oxidative stress in female reproduction. Reproductive biology and endocrinology. 2005; 3:28.

16. Shen M, Lin F, Zhang J, Tang Y, Chen WK, Liu H. Involvement of the up-regulated FoxO1 expression in follicular granulosa cell apoptosis induced by oxidative stress. The Journal of biological chemistry. 2012; 287:25727-25740.

17. Nakahara T, Iwase A, Nakamura T, Kondo M, Bayasula, Kobayashi H, Takikawa S, Manabe S, Goto M, Kotani T, Kikkawa F. Sphingosine-1-phosphate inhibits H2O2induced granulosa cell apoptosis via the PI3K/Akt signaling pathway. Fertil Steril. 2012; 98:1001-1008 e1001.

18. Chen HC, Kanai M, Inoue-Yamauchi A, Tu HC, Huang Y, Ren D, Kim H, Takeda S, Reyna DE, Chan PM, Ganesan YT, Liao CP, Gavathiotis E, et al. An interconnected hierarchical model of cell death regulation by the BCL-2 family. Nat Cell Biol. 2015; 17:1270-1281.

19. Marinho HS, Real C, Cyrne L, Soares H, Antunes F. Hydrogen peroxide sensing, signaling and regulation of transcription factors. Redox Biol. 2014; 2:535-562. 
20. Zhu H, Itoh K, Yamamoto M, Zweier JL, Li Y. Role of Nrf2 signaling in regulation of antioxidants and phase 2 enzymes in cardiac fibroblasts: protection against reactive oxygen and nitrogen species-induced cell injury. FEBS Lett. 2005; 579:3029-3036.

21. Sun SY. N-acetylcysteine, reactive oxygen species and beyond. Cancer biology \& therapy. 2010; 9:109-110.

22. Pitzschke A, Hirt H. Mitogen-activated protein kinases and reactive oxygen species signaling in plants. Plant physiology. 2006; 141:351-356.

23. Liu B, Chen Y, St Clair DK. ROS and p53: a versatile partnership. Free radical biology \& medicine. 2008; 44:1529-1535.
24. Ren D, Sun J, Mao L, Ye H, Polonsky KS. BH3-only molecule Bim mediates beta-cell death in IRS2 deficiency. Diabetes. 2014; 63:3378-3387.

25. Tu HC, Ren D, Wang GX, Chen DY, Westergard TD, Kim H, Sasagawa S, Hsieh JJ, Cheng EH. The p53-cathepsin axis cooperates with ROS to activate programmed necrotic death upon DNA damage. Proc Natl Acad Sci U S A. 2009; 106:1093-1098.

26. Rai P, Young JJ, Burton DG, Giribaldi MG, Onder TT, Weinberg RA. Enhanced elimination of oxidized guanine nucleotides inhibits oncogenic RAS-induced DNA damage and premature senescence. Oncogene. 2011; 30:1489-1496. 